\title{
JUURNAL_RU
}

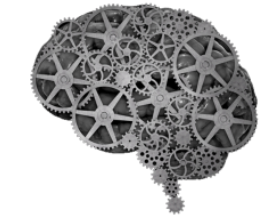

COMPANY GROUP "INTELLEKT"

\author{
Ященко О.В. \\ Башкирский Государственный Университет \\ Уфа, Россия
}

doi: 10.18411/1j2016-4-55

\section{Особенности домаших хозяйств Республики Башкортостан}

Структура региональной экономики определяется субъектами и объектами рыночных отношений. Основными субъектами рыночной экономики являются домашние хозяйства, предпринимательский сектор и правительство. Их взаимодействие через систему рынков сопровождается развитием разнообразных организационно-правовых форм ведения хозяйства, которое объективно формирует почву для конкуренции. Объектами этих отношений являются средства производства, труд, продукты труда (средства производства, предметы потребления, услуги, жилье, научные идеи, информация и тому подобное), ценные бумаги, валюта.

Этимология понятия «домашние хозяйства»

постепенно трансформировалась во времени под влиянием изменений в структуре производственных и потребительских взаимоотношений.

Основателем экономики семейного типа стал американский исследователь Г. Беккер, который всесторонне изучил систему функционирования домашнего хозяйства: особенности распределения труда между членами семьи, роль альтруизма для благосостояния и развития семьи [4; 7].

Важный вклад в понимание домашнего хозяйства как субъекта рыночных отношений внес российский ученый Айнабек К.С., выявив его отличие от предпринимательского сектора и государства. В российской научной среде сложились и другие точки зрения. Подчеркивая патриархальность в семейных 
отношениях, которая сложилась исторически, А. Олейник рассматривает домашнее хозяйство как особенный вариант властных отношений, когда право контроля над совместной экономической деятельностью передаются одному из его членов «главе семьи» [3, с. 58]. Однако, в социально развитых обществах принято гендерное равенство, поэтому и власть сегодня должна быть распределена как и обязанности.

Рассматривая «домашнее хозяйство», как экономическую категорию, О.А. Рогачева дает следующее определение: «Домашние хозяйства (домохозяйства) представляют собой совокупность лиц, проживающих в одном помещении или его части, как связанных так и не связанных родством, совместно обеспечивающих себя всем необходимым для жизни, полностью или частично объединяя и расходуя свои средства [4]. В своем определении автор фактически отражает устоявшуюся традиции ведения домашних хозяйств в гражданских браках, что фактически снижает уровень устойчивого развития семейных отношений, ухудшает мотивацию к накоплению, вложению долгосрочных инвестиций.

Из фундаментальных исследований Дж. Гэлбрейта, общеизвестно, что современное домашнее хозяйство требует простого, но очень важного разделения труда. Обычно получение дохода порождает решающую власть над его использованием, которая, как правило, принадлежит мужчине. Выбор места, где проживает семья, зависит главным образом от удобства или потребности члена семьи, обеспечивающего доход.

Домашние хозяйства играют важную роль в преобразовании человеческого потенциала в человеческий капитал, ведь именно в семье принимают решение о выборе профессии, получении уровня квалификации, инвестировании в образование, медицинское и социальное страхование.

Методика анализа в нашей статье численности и структуры домашних хозяйств Республики Башкортостан основывается на всестороннем изучении факторов, раскрывающих детерминанты развития. Макроэкономический анализ 
позволит выявить гетерогенные признаки развития гомогенных групп домашних хозяйств, с целью выявления принципиальных различий в положениях домашних хозяйств и их корреляционной взаимосвязи с региональной экономикой Республики Башкортостан.

По численности населения Республика Башкортостан находится на первом месте в Приволжском Федеральном округе и на седьмом - в Российской Федерации. На 1 января 2013 г. в республике проживало 4 060,9 тыс. человек, что составляет 2,8\% населения Российской Федерации. Большая часть жителей республики - горожане, они составляют 61,1\% населения; сельские жители 38,2\%. Средний возраст населения составляет - 38,7 лет.

Как видно из статистических данных, основное абсолютное преимущество для развития региональной экономики Республики Башкортостан, дает человеческий потенциал, благодаря которому она входит в ТОП-10 регионов по численности населения.

Однако, следует заметить, что согласно Всероссийской переписи населения удельный вес населения Республики в 2010 г. составлял 2.85\% , то есть за 4 года удельный вес Республики Башкортостан сократился на 0,5\%.

Стимулом для развития региональной экономики, является не столько количествнный состав населения, сколько его способность создавать материальные блага, уровень образования, физическое состояние, уровень его благосостояния.

Обращаясь к статистическим данным, следует отметить, что: «Башкортостан занимает в ПФО первое место по доле населения моложе трудоспособного возраста $(18,8 \%)$ и предпоследнее - по доле лиц старше трудоспособного (21,6\%). Для сравнения: в 2013 г. минимальная доля населения составила моложе трудоспособного возраста в Республике Мордовия (14,6\%); максимальная доля населения старше трудоспособного - в Пензенской области (26,8\%). Среди регионов ПФО в РБ один из самых высоких коэффициентов нагрузки на трудоспособное население лицами моложе трудоспособного 
возраста и самый низкий - пенсионерами. В итоге демографическая нагрузка на 1000 человек в трудоспособном возрасте составила 665 человек против 677 человек по ПФО. Население РБ моложе, чем в среднем по РФ и ПФО: средний возраст населения республики на 1 января 2013 г. составил 38,2, в РФ - 39,3, ПФО - 39,6 лет. Такая особенность возрастной структуры населения региона связана с длительным сохранением относительно более высокой рождаемости по сравнению с другими регионами ПФО. В то же время возраст примерно каждого девятого жителя республики превышает 65 лет (12\%). Негативной тенденцией социально-демографического развития республики является снижение численности лиц трудоспособного возраста, как и в большинстве субъектов России. В настоящее время в стране много граждан трудоспособного возраста, родившихся в годы социалистического «застоя». В дальнейшем все больше граждан, родившихся при социализме, будет переходить в возраст нетрудоспособных (на пенсию) и, с учетом провала рождаемости 90-х годов, нагрузка на работающих будет возрастать. К 2025 году «численность тех, кто может трудиться, сократится на 16 миллионов человек».

По нашему мнению, очевидным стал факт, что данную проблему можно разрешить только за счет внутренней или внешней миграции, что поможет привлечь высококвалифицированных специалистов и специалистов рабочих профессий на предприятия Республики Башкортостан. Для уменьшения потока мигрантов из сельской местности в региональном бюджете необходимо предусматривать больше средств на улучшение инфраструктуры сел, привлечение инвестиций домашних хозяйств в развитие фермерства, что послужит стимулом для обеспечения рабочими местами местного населения.

Всероссийская перепись населения 2010 г. зафиксировала в Республике Башкортостан 551,9 тыс. частных домохозяйств, в которых воспитывается 833,9 тыс. детей моложе 18 лет. Численность детей с 2002 г. (1052,6 тыс. чел., что составляло 25,6\% населения) снизилась, но в последние годы наблюдается тенденция роста: в 2010 г. - 20,5\%, в 2011 г. -20,8\%, в 2013 г. - 
$21,1 \%$.

Таким образом, государственная программа по поддержке рождаемости, в виде предоставления материнского капитала дала положительные результаты, повлияв на рост рождаемости. Однако, эффект будет более весомым, если эта льгота будет монетизирована в будущем, поскольку тенденция к сокращению рождаемости в домохозяйствах будет сохраняться и в будущем. Об это свидетельствуют нижеприведенные статистические данные.

Исходя из статистических данных по Республике Башкортостан, абсолютное и относительное число браков снизилось в кризисные 1990-е годы. (до 7,6 на 1000 чел. в 1994 г.) и стабилизировалось в последние годы (на уровне 9,4-9,2 на 1000 чел. в 2011-2012 гг.).

Абсолютное и относительное число разводов растет на протяжении длительного времени (с 2,8 в 1990 г. до 4,4 на 1000 чел. в 2012 г.) и составляет в среднем 16-17 тыс. в год. За 9 месяцев 2013 г. зафиксировано больше разводов по сравнению с аналогичным периодом предыдущего года. Браки стали менее прочными: число разводов на 1000 браков в республике за последние 20 лет выросло почти в 2 раза (с 231 в 1990 г. до 522 в 2012 г. на 1000 браков). В 2012 г. основная часть разводов приходилась на пары с длительностью браков 2-4 года $(27,5 \%)$ и 5-9 лет $(24,3 \%)$. В более чем 20\% распавшихся парах были несовершеннолетние дети (6778 детей).

Особая категория - семьи с одним родителем, которые составили, по данным ВПН 2010 г., 25\% всех семейных ячеек. Абсолютное их большинство - матери с детьми (90\%). Доля однодетных среди таких семей выше, чем у всего населения в среднем.

Как видно из статистических данных, трансформации в обществе негативно отразились на структуре домохозяйств, поскольку увеличивается число разводов и уменьшается количество лет, прожитых в браке. В результате снижается мотивация к выполнению социально-культурной функции, которая выражается в социализации человека, адаптации в обществе, передаче 
культурных традиций, преемственности в выполнении определенных профессионально-трудовых функций (семейные династии).

Ученые связывают изменения в ценностных трудовых ориентациях российской молодежи с ухудшением материального благополучия большинства граждан и резким на этом фоне обогащением отдельных групп населения. Опросы 2005-2009 гг. показывают, что $15-20$ \% молодых респондентов не стали бы работать вообще, если бы были материально обеспечены. Около 40-50 \% молодых людей связывали мотивацию трудовой активности с деньгами и стремлением заработать их любыми способами, в том числе и противоправными, что, в свою очередь, не могло не вызывать беспокойство у российских учених. Проведенный социально-экономический анализ положения домашних хозяйств показал, что в период становления новых субъектов хозяйствования, к сожалению происходит их постепенное уменьшение. 


\section{Литература:}

1. Семья и человеческое развитие. Доклад о развитии человеческого потенциала в Республике Башкортостан / под общ. ред. Р.М. Валиахметова, Ф.Б. Бурхановой, Г.Ф. Хилажевой. Уфа: Изд-во «Восточная печать», 2013. 283 с.

2. Республика Башкортостан. Демографический доклад. Выпуск 1 /отв. ред. Р.М. Валиахметов, Г.Ф. Хилажева. Уфа: Восточная печать, 2014. 196 с., с 8.

3. Becker G.S. An Economic Analysis of Fertility // Demographic and Economic Change in Developed Countries: A Conference of the Universities-National Bureau Committee for Economic Research. Princeton University Press for the NBER, 1960.

4. Экономические субъекты постсоветской России (институциональный анализ) : десять лет спустя. Часть I. Российские домохозяйства / Под редакцией д. э. н. . проф. Р.М. Нуреева. Серия «Научные доклады: независимый экономический анализ», № 212, часть I. Москва, Московский общественный научный фонд, 2010, 196 с. 